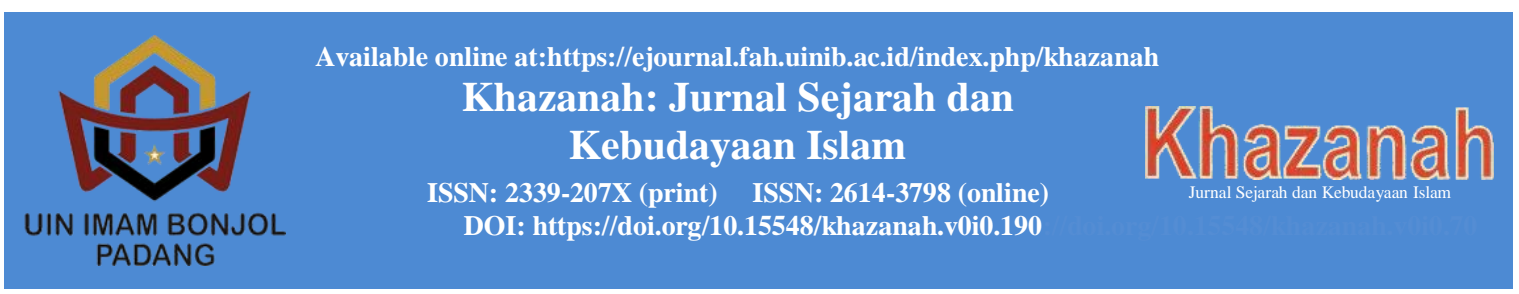

\title{
REFORMING THE ISLAMIC ECONOMIC AND ADMINISTRATION SYSTEM DURING THE UMAYYAD DYNASTY
}

\author{
Muhammad Ridho Nur \\ UIN Imam Bonjol Padang \\ ridhonur@gmail.com
}

\begin{abstract}
The rule of the Bani Umayah was not strictly an Evil government as described by history. However, the Bani Umayan administration had advantages in various fields, especially in administration and an established economy. Friction with old empires such as Persia and Byzantium had influenced the Umayyad administration system. The filing of the Bani Umayah was more orderly, and the balance sheets began to be compiled in Arabic after the translation efforts of various documents started. This was done because the Bani Umayah area was extensive, starting from France, Italy, Sicily, Spain, North Africa to China and Russia's borders. The author conducted a literature study, collected verification documents, and reinterpreted them. The author rewrote the Umayah Bani economy's historical development, which had unique features, especially in the financial administration midwives. That was carried out by reformers such as Abdul Malik bin Marwan and Umar bin Abdul Aziz who had aged a country with experienced upheaval. Avoid premature destruction. They renewed the monetary system by creating their own currency, which had intrinsic value and did not depend on the Roman Empire and increased production to support the stability of a coin that not only relies on the strength of a more stable gold currency but was also supported by a factor of production which was also a factor. Prominent in a country that has a large area in realizing its economic stability.
\end{abstract}

Keywords: Administration, Economic, Umayyad

\section{INTRODUCTION}

After the reign of Khulafa Rasyidin or after the caliph Ali bin Abi Talib was killed by Abdur Rahman bin Muljam, the transfer of power from Ali bin Abi Talib (4th Rashidin caliph) to the Umayyad Daulah. This is a history of intricacy, so that it deserves to be examined and studied more in-depth.
Not only that, the political struggle that occurred at the beginning of the Umayyad Daulah, to the development and change of the Khilafah system into a Daulat (Dynasty) is fascinating to examine. This is where the conversion of the model of government from democratic to monarchy begins. But we also cannot close our eyes; even though 
various problems occurred at that time, the Umayyad Daulah, which has been in power for approximately 90 years, has also significantly contributed to building Islamic civilization in the world. Many advances have been scratched in Islamic culture by the Umayyad Daulah, including politics, government, military, social society, education, art, thought, philosophy, and religious understanding, especially economics. This problem is related to introducing the financial administration system and government and the Umayyads economy. Is it Bani Umayah, how do Bani Umayah develop their economy. By paying attention to the background of the problems above, in this study, the following issues were formulated: ${ }^{1}$

This writing aims to get to know the Bani Umayah economic and administrative system and its reforms. This paper's novelty discusses the reforms carried out by Abdul Malik bin Marwan in financial administration and governance, which later ran more effectively during Umar bin Abdul Aziz's time. $^{2}$

\section{DISCUSSION}

The Establishment of the East Umayyads (Damascus Area)

Bani Umayyah is taken from Umayyah, his grandfather Abu Sofyan bin Harb, or his ancestor Muawiyah bin Abi Sofyan. Umayyah lived in preIslamic times, and he was a Quraish nation. Daulah Bani Umayyah was founded by Muawiyah bin Abi Sufyan with his government's centre in Damascus and lasted for 90 years (41 $132 \mathrm{H} / 661-750 \mathrm{AD}){ }^{3}$

\footnotetext{
'Īsá Hasan, al-Dawlah al'Umawīyah: 'awāmil al-binā' wa-asbāb alinhiyār, al-Ṭab'ah 1 edition ('Ammān: alAhlīyah lil-Nashr wa-al-Tawzī‘, 2009), p. 57.

${ }^{2}$ Meirison Alizar Sali, 'Distinction of Justice and Fairness during Umar bin Abdul Aziz?s Reign', AJIS: Academic Journal of Islamic Studies, vol. 4, no. 2 (2019), p. 127.

3 Yahya Hakim, 'The HashemiteUmayyad Divide and its Impact on the Future of
}

Muawiyah bin Abi Sufyan was well known for his cunning tricks and tricks, he was the head of the army that initially governed the navy, and he was once the emir of Al-Bahar. He has a long-minded nature, is intelligent, smart, wise, broad in knowledge and tactics, especially in world affairs; he is also good at managing work and is an expert on wisdom.

Muawiyah bin Abi Sufyan built the Daulah Bani Umayyah using tricky politics, even though the work was against Islamic teachings. $\mathrm{He}$ is not afraid of committing crimes. Killing is the usual method, provided the aims and objectives are achieved. ${ }^{4}$

The formation of the Umayyad Daulah cannot be separated from the taking incident, which occurred at the end of the Caliphate of Ali bin Abi Talib. In the event of the Tahkim, Ali had been deceived by Muawiyyah's tactics, and in the future, he suffered political defeat. Meanwhile, Muawiyyah had the opportunity to make himself caliph and king.

Daulah Bani Umayyah, based in Damascus, has been ruled by 14 caliphs. However, among the caliphs, the most prominent were: Khalifah Muawiyah bin Abi Sufyan, Abdul Malik bin Marwan, Walid bin Abdul Malik, Umar bin Abdul Aziz and Hisyam bin Abdul Malik. ${ }^{5}$

\section{Government and Policy of the Umayyads}

Daulah Bani Umayyah has been able to expand, which was stopped at

Islam: The Hashemite-Umayyad Divide and its impact on the future of Islam', The Muslim World, vol. 106, no. 1 (2016), pp. 83-96.

4 Philip K. Hitti, 'The Umayyad Caliphate: Mu'āwiyah Establishes a Dynasty', in History of the Arabs (London: Macmillan Education UK, 1970), pp. 189-98, http://link.springer.com/10.1007/978-1-34915402-9_17, accessed 8 Sep 2020.

${ }^{5}$ Ismā'îl ibn 'Umar Ibn Kathīr, The caliphate of Banu Umayyah: the first phase: taken from al-Bidayah wan-nihayah (Riyadh: Maktaba Dar-us-Salam, 2012), p. 77. 
Ali's time, Tunisia can be conquered. In the east, Muawiyah controlled the Khurasan area to the Oxus river and Afghanistan to Kabul. Its navy carried out attacks on the Byzantine capital, Constantinople. Muawiyah's expansion to the east was then continued by the caliph Abd al-Malik. He sent soldiers across the Oxus river and successfully subdue Balkh, Bukhara, Khawarizm, Ferghana, and Samarkand. His army even reached India and was able to control Baluchistan, Sind, and Punjab as far as Malta. ${ }^{6}$

The West's expansion was continued on a large scale during the time of al-Walid ibn Abdul Malik. Walid's reign was a time of peace, prosperity, and order. ${ }^{7}$ Muslims feel happy life. During his reign, which lasted for about ten years, a military expedition from North Africa was recorded to the European continent's southwestern region, namely in 711 AD. After al-Jazair and Morocco were defeated. Tariq bin Ziyad, leader of the Islamic forces, with his troops crossed the strait that separated Morocco from the continent of Europe and landed in what is now Gibraltar (Jabal Tariq). The Spanish army can be defeated. Thus, Spain became the target of further expansion. The capital of Spain, Kordova, quickly took over. ${ }^{8}$

He was following after those other cities such as Service, Elvira, and Toledo, which became the new capital of Spain after the fall of Kordova. ${ }^{9}$ The

${ }^{6}$ Antoine Borrut et al. (eds.), Umayyad legacies: medieval memories from Syria to Spain (2010), p. 111.

7 Meirison Meirison, 'Islamic Tolerance on Religious Freedom, Culture and Thought in Andalusia', HIKMATUNA; Vol 6 No 1 (2020): HIKMATUNA: Journal for Integrative Islamic Studies, Juni 2020DO 10.28918/hikmatuna.v6il.2313 (2020), http://ejournal.iainpekalongan.ac.id/index.php/hikmatu na/article/view/2313. legacies, p. 45.

8 Borrut et al. (eds.), Umayyad

9 Meirison, 'Islamic Tolerance on Religious Freedom, Culture and Thought in Andalusia'.
Islamic troops won easily because they received the local people's support, who had long suffered from the authorities' cruelty. In Umar ibn Abd al-Aziz's time, attacks were carried out on France through the Piranee mountains. Abdurrahman ibn Abdullah al-Ghafiqi led this attack. He started by attacking Bordeau, Poitiers. From there, he tried to attack Tours. However, in a battle outside the Tours city, al-Ghafiqi was killed, and his soldiers retreated to Spain. Apart from the areas mentioned above, the islands in the Mediterranean Sea fell into Islam's hands during the Umayyads. Muawiyah appeared as the first Ruler to change the Islamic government system, from a democratic government system to an absolute monarchy government system. For 90 years, 14 caliphs had ruled, namely: ${ }^{10}$

a. Muawiyah bin Abu Sufyan (Muawiyah I) - (661M-680M)

b. Yazid bin Muawiyah (Yazid I) (680M-683M)

c. Muawiyah bin Yazid (Muawiyah II) (683M-684M)

d. Marwan bin Hakam (Marwan I) (684M-685M)

e. Abd Malik bin Marwan - (685M$705 \mathrm{M}$ )

f. Walid bin Abd Malik (Walid I) (705M-715M)

g. Sulaiman bin Abd Malik - (715M$717 \mathrm{M})$

h. Umar bin Abdul Aziz (Umar II) (717M-720M)

i. Yazid bin Abd Malik (Yazid II) (720M-724M)

j. Hisham bin Abd Malik - (724M743M)

k. Walid bin Yazid (Walid III) - (743M744M)

1. Yazid bin Walid (Yazid III) - (744M)

m. Ibrahim bin Walid - (744M)

n. Marwan bin Muhammad (Marwan II) - (744M-750M)

All the Umayyad dynasty's caliphs were not appointed through the

\footnotetext{
${ }^{10}$ Hasan, al-Dawlah al-'Umawìyah, p.
} 138. 
Shuro Council but instead used the inheritance system to befits a kingdom. Therefore, according to Abu A'la Maududi, they do not deserve the title Khalifah as befits Khulafaur Rasyidin. They have carried out succession changes and a deliberative system that involves the ummah, especially in policy matters in general, as was used by Khulaur Rashdin before. Even society's control over them is minimal, not even at all. ${ }^{11}$

The succession of hereditary leadership began when Muawiyah obliged all of its people to declare loyalty to their son, Yazid bin Muawiyah, to emulate monarchy in Persia and Byzantium. He did keep using the term Khalifah, but he gave a new interpretation of these words to glorify the office; he called him Khalifah Allah in the sense of the Ruler appointed by Allah. ${ }^{12}$

Like the Islamic civilization, Islamic politics must have clear definitions and boundaries. According to Effat Al-Sharqawi, there can be fundamental differences between Islamic politics and the Muslims' politics. Islamic politics is a rule of thumb in gaining and maintaining power based on Islamic values, while the politics of the Muslims are more inclined towards parties or groups. Meanwhile, regarding the history of the formation of the Islamic political system during the Umayyad dynasty. Many historical experts admit that since the establishment of this dynasty, there has been a different political system from the four Rashidah caliphs. Amawiyah further emphasized his Arabic political style. According to Ali Husni Al-Kharbutily, Muawiyyah - the first founder of the Bani Mayyah Dynasty - was an intelligent person and

\footnotetext{
11 Naila Farah, PERKEMBANGAN EKONOMI DAN ADMINISTRASI PADA MASA BANI UMAYYAH DAN BANI ABBASIYAH, p. 26.

${ }^{12}$ Hakim, 'The Hashemite-Umayyad Divide and its Impact on the Future of Islam'.
}

was very skilled in Siyasa. Therefore, at the beginning of the dynasty's establishment, it divided its territory into five fronts of political power, namely: ${ }^{13}$

The Arabian Peninsula front includes a green cover for Hijaz, Yemen, Makkah, and Medina, an Egyptian Front covering all of Egypt. The Iraqi Front covered the Persian Gulf, Aman, Bahrain, Sijistan, Kirman, Khurasan to Indian Punjab, and the Minor Asian Front, including Armenia and Azerbaijan's territories and the African Front, which consists of the Barbarian region, Andalusia and the countries around the Mediterranean. ${ }^{14}$

According to Mahayudin, for each of these regions, different political rules are applied. For example, on the Arabian Peninsula-Makkah, Madinah, and Iraqi Front, soft political policies were implemented because the people in both regions were classified as supporters of Ali bin Abi Talib and Zubair bin Awam. ${ }^{15}$ Various approaches were taken, from psychological approaches to social welfare approaches. All of this is intended to gain influence and support from the surrounding community.

a. Cultural Friction and Civilization

In general, the development of Islamic civilization during the Umayyah era was the socialization of Arabic culture in all socio-cultural layers in its conquered areas. This Arabization's primary mission still implies that the Arabic-speaking

\footnotetext{
علام، عز الدين, الآداب السلطانية: دراسة في 13

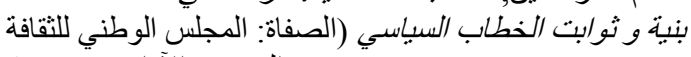
و و الفنون و الآداب،, 2006 الوطني 2. 91.

14 Borrut et al. (eds.), Umayyad legacies.

${ }^{15}$ G.R. Hawting, The first dynasty of Islam: the Umayyad caliphate AD 661-750, 2nd ed edition (London; New York: Routledge, 2000).

شمري، هزاع بن عيد،, معجم رجال الدولة 16 الأموية (Hazzā' ibn 'Îd al-Shammarī, 2012), p. 51 ,

https://books.google.co.id/books?id=BGvGoAE ACAAJ.
} 
population in all regions of the world can almost be Muslim or known as Islam. This Arabization policy indirectly impacts or accumulates from and for their interests. Umayyah I policies include: ${ }^{17}$ Appointed the Arabs to develop the leadership of Muslims in all the regions he had conquered.

b. Arabic as the primary language of the people, both in administrative and scientific development.

c. The interests of outsiders to understand Islamic sources are required to master Arabic structure and culture to give birth to various linguistics; Nahwu, Sharaf, Balaghah, Bayan, Badi ', Isti'arah, and so on.

d. The development of religious sciences has begun to be developed because it feels that the Arabian Peninsula inhabitants need various explanations and a systematic and chronological description of Islam. The sciences that developed included interpretation, hadith, fiqh, Ushul Fiqih, kalam knowledge, and Sirakh / date.

During the time of the Bani Umayyah, the culture had developed from the previous period. Among the Islamic cultures that have experienced developments are literary arts, fine arts, sound art, building art, carving skill, etc. At this time, many buildings were engineered by Muslims by taking Roman, Persian and Arabic patterns. Examples are the Damascus mosque building built during the reign of Walid bin Abdul Malik and the Great Cordova mosque made of alabaster. Literary art is developing rapidly to penetrate the human soul and has a high position in society and the country. So that the lyrics that always appear often stand out from the literature, in addition to their high-quality content. ${ }^{18}$ In the art of

${ }^{17}$ Salma Khadra Jayyusi and Manuela Marín (eds.), The legacy of Muslim Spain, 2nd ed edition (Leiden; New York: E.J. Brill, 1994). ${ }^{18}$ Ibid., p. 67. sound that has developed is the art of reading the Qur'an, Qasidah, music, and songs that breathe love. So that at that time, famous artists and Qori '/ Qori'ah emerged. The most prominent development of carving is the use of Arabic Khotas as a carving or carving motif. This can be seen from the number of mosque walls and palace walls measured by Arabic khat. One of them that is still left behind is a carved wall of the Qushair Amrah (Amrah's Tiny Palace), a summer palace in a mountainous area located approximately 50 miles east of Amman. ${ }^{19}$

In science, developments include religious science and general science, such as medicine, philosophy, astronomy, exact science, earth science, history, etc. At this point too, politics has undergone progress and change, so that it is more orderly compared to the previous period, especially in terms of the Khilafah (leadership), the formation of Al-Kitabah (State Secretariat), AlHijabah (Adjutant), Financial Organizations, Judicial Organizations, and Organizations. State Administration. During the Umayyads, military strength was far more developed than before because the Military Compulsory Law (Nizhamut Tajnidil Ijbary) was enacted. Whereas in the previous period, namely the Khulafaurrasyidin period, the army was a volunteer force. The Umayyad army politics in Arab politics, where the soldiers must be Arabs themselves or from Arab elements. At this time also, a nearly perfect Islamic Fleet had been built up to 17,000 ships that could easily conquer Rhodus Island with its commander Admiral Aqabah bin Amir. Besides that, Muawiyah has also formed the "Summer Fleet and Winter Fleet," making it possible for him to fight in all seasons. ${ }^{20}$ In the field of socio-culture, during the Umayyads' time, the

\footnotetext{
مقريزي، أحمد بن علي, النزاع والتخاصم فيها 19

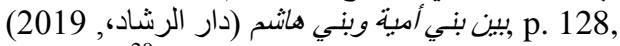
${ }^{20}$ Ibid., p. 78.
} 
Khalifah had also contributed quite a lot, namely, with the construction of the first hospital in each city by Khalifah Walid bin Abdul Malik. At that time, a halfway house was built for orphaned children abandoned by their parents due to the war. Even the elderly who can no longer afford it are cared for in these houses. These efforts generate high enough sympathy from non-Muslims, which in the end, they embrace Islam in droves. $^{21}$

\section{History of Islamic Economic Thought during the Umayyads}

The successes achieved by the Umayyads provided a different form of economic thought, precisely when the Islamic world was under the leadership of the Umayyad Caliphs. The condition of Baitul Maal changed. During the reign of the Umayyads, Baitul Maal was divided into two parts; general and particular. General Baitul Maal's income is earmarked for all the general public, while Baitul Maal's income is specifically for the Sultans and their families. However, it is not uncommon in practice to find various irregularities in distributing the Baitul Maal property. Thus the use of Baitul Maal had dysfunction during the reign of the Umayyad Daula. Among the Umayyad Caliphs who were renowned and gave a lot of thoughts in the economic field were: ${ }^{22}$

\section{Caliph Muawiyah ibn Abi Sofyan}

During his reign, he established a postal service and various facilities, disciplined the army, made money, and developed a professional position. He also implemented a policy of providing fixed salaries to soldiers, establishing a professional army, and developing

${ }^{21}$ Josep Suñé Arce, 'Was the Umayyad Caliphate of Cordoba as Strong as Arab Chroniclers Claimed?', Al-Masāq, vol. 31, no. 1 (2019), pp. 35-49.

http://referensiagama.blogspot.com/2011/01/ko nsolidasi-dan-pembaharuan-politik.html bureaucracy such as tax collection and administrative functions.

\section{Caliph Abdul Malik ibn Marwan}

Painful thoughts for the issuance and regulation of money in Islamic societies arose during his time. Abd alMalik changed the Byzantine and Persian currencies used in areas controlled by Islam. Thus, he printed his currency using Arabic words and writings and kept the sentence Bismillahirrahmanirrahim in 74 A.H. (659 AD). The making of money was based on the idea that currency, besides economic value, was also a statement of the Islamic dynasty's sovereignty. Besides, capital also served as a means of announcing the government's validity at that time, whose name was imprinted on the currency. ${ }^{23}$ There are two main types of money in the Islamic world: the gold dinar, taken from the word denarius, and the silver dirham, which comes from the Greek word drachmas. Apart from these two types, there are fractional currencies or maxims such as Qitha and Mithqal.

During the four hijrahs, the Islamic world experienced a gold and silver currency crisis. It was made of copper or a mixture of copper and silver called Fulus (taken from Latin follis), which is thin copper currency. The currency is also called al-Qarathis because it is similar to a sheet of paper. ${ }^{24}$ After the currency, currency money began to be calculated. After many coins labeled as Khalifah, there emerged a group of people who provided services in facilitating financial transactions and currency exchanges called currency exchangers

\footnotetext{
Developing Inclusive and Sustainable Economic and Financial System: Selected papers presented to the 8th and 9th International Conference on Islamic Economics and Finance (Qatar: Bloomsbury Qatar Foundation Journals, 2015).

${ }^{24}$ Hawting, The first dynasty of Islam.
} 
(as-Shayyarifah). ${ }^{25}$ Besides, an economic term appears, which indicates that the place of conversation has changed its function to become a bank. The Caliph Abdul Malik, in terms of taxes and zakat, provided a policy by imposing an obligation for Muslims to pay zakat and be free from other taxes. This encourages non-Muslims to embrace Islam. In this way, they are free from paying taxes. After that, they left their farms to make a living in big cities as soldiers. This fact creates problems for the country's economy. However, Caliph Abdul Malik bin Marwan returned some of the Islamic militaries to their original profession, namely farmers, and stipulated them to pay several taxes as their obligation before converting to Islam, which was equal to the burden Kharaj and Jizyah.

Caliph Abd al-Malik also succeeded in reforming government administration and enforcing Arabic as the official Islamic government administration language. The Caliph Abd al-Malik's success was followed by his son al-Walid ibn Abd al-Malik (705715 AD), a strong-willed and capable of carrying out development.

\section{Khalifah Umar ibn Abdul Aziz}

During his reign, he reimplemented Islam wholly and entirely. He also surrendered all his and his family's property, which was unnatural to the Muslims, through Baitul Maal. $\mathrm{He}$ also protects and enhances the prosperity of society as a whole.

Umar also tried to clean Baitul Maal from illegitimate assets and wanted to distribute them to those entitled to receive them. And ordered his subordinates to Amir so that they would return unlawful property. To protect and increase his people's prosperity, he reduced the tax burden imposed by Christians, abolished taxes for Muslims, made measurements and

25 H. Boedi Abdullah and H. Hendi Suhendi, Peradaban pemikiran ekonomi Islam (Bandung: Pustaka Setia, 2010), p. 79. weights, eradicated excise and forced labor, and so on. Various policies have succeeded in increasing people's lives so that no one wants to accept zakat anymore. In the early days of the Umayyad dynasty, many of the rights of orphans left by Muslim fighters were taken away; even their rights were not given. Seeing this fact, Umar bin Abdul Aziz issued a policy to return all their property. This action generated a positive response and brought fragrance to his name and the name of the Umayyads. Caliph Umar bin Abdul Aziz also established a policy of reducing the tax burden for Christian Najran from 2000 pieces to 200 pieces because it turned out that most of the Najran people were not rich. He also prohibited the purchase of non-Muslim land to Muslims because many Christian lands had become Muslim so that Christians had no land to cultivate. Also, he obliges Kharaj to Muslims and jizyah (life tax) to non-Muslims. ${ }^{26}$ Furthermore, the Caliph Umar Ibn Abdul Aziz implemented the regional autonomy policy. And each Islamic region has the authority to manage zakat and taxes independently and is not required to hand over tribute to the central government. Even the government will provide subsidies to Islamic areas with minimal zakat and tax revenues. ${ }^{27} \mathrm{He}$ also appointed Ibn Jahdam as Amil Sadaqah, who was in charge of distributing Sadaqah evenly. During his reign, state income sources came from zakat, spoils of war, and agricultural income. After the community's economic stability improved, taxes were set; however, the Baitul Maal condition that Umar Ibn Abdul Aziz had returned to a position that did not last long. The greed of the rulers has faded the joints of the Baitul

26 Sali, 'Distinction of Justice and Fairness during Umar bin Abdul Aziz $>$ s Reign'.

${ }^{27}$ Ibid. 
Maal. This situation continued until the time of the Abbasid caliphate ${ }^{28}$.

\section{Economic Activities during the Umayyad Caliphate}

In pre-Islamic times, Roman and Persian coins were used in the Hejaz and some Himyary silver coins bearing the Attic owl. Umar, Muawiyah, and other previous Khalifah felt that they had enough foreign currency in circulation, and maybe in some cases, there were quotes from certain Quranic verses on the coins. During Abd AlMalik's time, various gold and silver coins had already been minted, but the print was just a reproduction of the Byzantine and Persian currencies. In 695, Abd Al-Malik minted gold dinars and silver dirhams, which were pure Arab works. $^{29}$ The Iraqi district, Al Hajjaj, printed money in Kuffah the following year. Apart from making Islamic money and Arabizing the administration of justice, Abd Al-Malik also developed a postal service system, using horses between Damascus and other provincial capitals. The service is designed primarily to meet the transportation needs of government officials and their correspondence issues. All post heads have to record and send the caliph all critical events in their respective territories. Concerning the change of eyes, we need to pay attention to the financial system reforms and the administration. No Muslim, of any nation, is burdened with paying taxes, other than zakat or compensation for the poor. However, in practice, privileges are often granted to a handful of Muslim-Arabs. Realizing that anchovies, many oaring who just converted to Islam, mostly from Iraq and Khurasan, started leaving the villages where they worked as farmers,

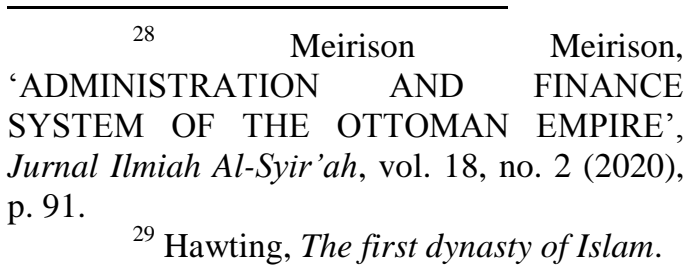

and went to the cities, hoping to join them as Mawali Soldiers. This phenomenon ended up causing double losses to the royal treasury. This is because after converting to Islam, tax revenues are significantly reduced, and after becoming a prisoner, they are entitled to subsidies. Al-Hajj then made important policies to return the people to their fields and again obliged them to pay the agricultural land and head taxes. He even required the Arabyang people to control land in the taxpayer's territory to pay land tax. After Daulah Umawiyah succeeded in preventing a large enough area, the trade traffic was adequately guaranteed. Land traffic through the Silk Road $\mathrm{Kr}$ China facilitates trade in silk, ceramics, medicines, and fragrances. The development of this trade has led to increased prosperity for the Umawiyah Daula. Economic fields that existed at the time of the Umayyads proved successful in bringing progress to the people, namely:

- In the field of agriculture, Umayyah has supported the development of the agricultural sector, he has introduced an irrigation system to increase agricultural output.

- In the industrial sector, especially craftsmanship has become the pulse of economic growth for the Umayyads.F. Economic Policy and Economic Practice

During the Umayyad's reign, many economic policies were formed based on the fuqaha and ulama's ijtihad. That was due to the different length of time (approximately one century) between the Prophet's life and reign. Various essential notes regarding the rule of the Umayyads can be explained as follows:

1. Muawiyah was a noble friend even though he did political ijtihad fighting against the Caliph Ali bin Abi Talib. It turned out that the ijtihad he did was not valid. However, he is still fair, and all his friends are honest. Marwan bin Hakam, one of the caliphs, was one of 
those who narrated many hadiths. Caliph Abdul Malik was known as a knowledgeable person and an expert in fiqh, and he was included in the scholars of Medina before being appointed as caliph. Umar bin Abdul Aziz was an Imam during ijtihad and was considered the 5th caliph of al Rashidun.

2. The conquest of several cities and countries to China's territory in the east, the countries in Andalusia, and the south of France in the West. At that time, Islamic rule settlement reached an extensive area throughout Islamic history, and many people embraced Islam.

Some of the traditions and practices carried out by the Umayyads during the Daulat al-Islam, namely:

1. When he was appointed Caliph, Umar bin Abdul Aziz gathered the people. He announced and handed over all his personal and family assets obtained inappropriately to Baitul Maal. These include plantation lands in Morocco, various allowances in Yamamah, Mukaedes, Jabal Al Wars, Yemen, and Fadak, to the diamond ring given by Al Walid.

2. During his reign, he also did not take anything from the Baitul Maal, including Fai's income, which was due to him.

3. Prioritizing domestic development. According to him, improving and enhancing Islamic countries' welfare is better than increasing the territory's expansion. In this context, he maintains good relations with the opposition and gives the right to worship freedom to other religions' followers.

4. In carrying out his various policies, Caliph Umar bin Abdul Aziz was more protective and improved the community's standard of living as a whole.

Volume 11, Nomor 1, Januari-Juni 2021
5. Abolishing taxes on Muslims, reducing the tax burden on Christians, making rules of measurement and weighing, eradicating excise and forced labor,

6. Improving agricultural land, digging wells, building roads, constructing travelers' accommodation places, and providing support for the poor. These various policies have succeeded in increasing the community's standard of living as a whole so that no one wants to accept zakat anymore.

7. Determining the official salary of 300 dinars and the official is prohibited from doing side work. The tax imposed on non-Muslims only applies to three professions: traders, farmers, and landlords.

\section{Renewal of Umar bin Abdul Aziz}

The arrival of the Caliph Umar Ibn Abd Al-'Aziz was an oasis in the desert, which brought a breath of fresh air in the Caliphate's history after about half the century Umayyad Caliphate. Even though the Caliphate of Umar was very short, he was able to show an independent period, had its characteristics, and contained a pure Islamic philosophy that was not influenced by the rules of some of the Umayyad caliphs, which were full of bloodshed and dictatorship ${ }^{30}$.

Umar Bin Abdul Aziz appeared at the historical crossroads of Muslims under the leadership of the Umayyad dynasty. At the end of the first century Hijriyah, this dynasty entered its sixtieth, or two-thirds of its age, and was already undergoing severe internal decay. Umar himself was part of this dynasty, in almost every way. Although he is a scholar who has mastered all the sciences of Medina's scholars, he is personally a symbol of the Umayyad dynasty's corrupt, luxurious and

\footnotetext{
${ }^{30}$ Ibn Kathīr, The caliphate of Banu Umayyah, p. 79.
} 
extravagant lifestyle. That made him not confident enough to lead when the royal family asked him to replace Sulaiman Bin Abdul Malik Bin Marwan after he died. It was not only because of the kingdom's complex internal problems but also because he was a part of the problem. It is a thing of the past. But the choice of him, for the royal family, was a must because Umar is the most appropriate figure for this position. When Umar finally accepted this position, he told a scholar who sat beside him, Al-Zuhri, "I fear hell." And a series of heroic stories had started from here, from fear of hell, when he was 37 years old and ended two years and five months later, or when he was 39 years old, with one fact: total reform has been carried out, justice has been served, and prosperity has been achieved.

By most historians, Umar is also considered the fifth Khulafaurrashidin or the caliph's continuation after Abu Bakr and Umar bin Khoththob of Umar II. It is deserving of this predicate because the reforms carried out could restore the caliphate chain that was cut off from Abu Bakr; Umar bin Khothob again appeared in the time of Umar Ibn Abd Al-'Aziz. So in this discussion, it is crucial to discuss the issue of political consolidation and renewal of Umar Ibn Abd Al-'Aziz as our knowledge and deepening of the development of Islamic civilization, which is a milestone at the beginning of a new history of culture after Khulafaurrasyidin. Umar Bin Abdul Aziz was well aware that he was a part of the past. He could not possibly make improvements in the life of a vast country unless he dared to start with himself, then continue it to his prominent family and then to the larger royal family. So the first step he had to take was to clean himself, his family and the royal palace. It was with that determination that he began a significant, lasting reform in history. ${ }^{31}$

After Umar became a caliph, Caliph Sulaiman's burial was carried out. Caliph Umar came to the king's vehicle in the form of a riding camel and goods carrier offered Umar; There was only one camel caught. The others were sold, and the results were moved to the Baitul Mal. Likewise, with the rugs, Khalifah's footwear was also sold to be given to the Baitul Mal. Umar also handed over all the land and assets he owned to Baitul Mal because it was believed that the inherited property was not his right but the people's freedom. Likewise, this attitude was applied to his wife to choose to follow Umar's path or leave him to return to his family because Umar realized that his wife was a person who had never felt the misery of a lack of wealth. Still, Fatimah Binti Malik chose to stay with her husband until the end of his life so that the assets he had were handed over to Baitul Mal and left only a little. Umar also avoided eating delicious food and refused to be served instead of helping himself. The clothes he wore were plainclothes; Ibn' Abdil Hakam reported that the clothes costing 8 dirhams were still excellent, long before Umar became caliph, his clothes costing 800 to 1000 dirhams. The hair that had been lengthened was cut, and Umar washed from the scented oil. He sold all the clothes and fragrances on him and gave the money to the Baitul Mal. His life pattern changed, from a world lover to a Zahid who only seeks an eternal afterlife. Umar did not want to live in the palace, and he only lived in a simple house near a mosque. Umar's attitude, which has changed very far from his habit so far, shows us that most leaders are poor before becoming leaders and become rich when leading, which does not apply to Umar. $\mathrm{He}$ was rich before becoming caliph and poor after becoming caliph. These steps to clean up oneself, family, and palace have convinced the public of the strong political will to carry out reforms in state life, especially in cleaning up collusion, corruption, and nepotism. Umar, a leader, has shown his determination and has set such a fantastic example.

31 Hakim, 'The Hashemite-Umayyad Divide and its Impact on the Future of Islam'. 


\section{Renewal in his reign}

The emphasis in Umar's political field was more on domestic reform. Warfare and conquest activities were stopped, the soldiers besieging Constantinople were all withdrawn, as were those in the former Byzantine colony. The goal is to provide security and provide opportunities for soldiers to rest and return with their families. Umar prefers peace in solving problems. The dialogue was one of Umar's ways to deal with domestic enemies, and this was done when he discussed with the Khawarij. Umar convinced the Khawarij with arguments and information that could satisfy their hearts. The point is that they can accept Umar's opinions so that there was no apparent domestic conflict at this time. The governors who were unjust and arbitrary were fired, and he chose governors or officials who could hold the mandate. Even the Caliph Umar dismissed Jarrah bin Abdillah Al-Hukmi, the governor of Khurasan, the governor he chose but was unable to carry out his duties as he hoped. Jarrah bin Abdillah was caught taking jizyah from the converts. At this time, there was no corruption, collusion, and nepotism because Umar chose officials according to their capabilities. Three thousand dinars raised Their wages to keep them from betraying the governors, and the next step is to strengthen state income source by relying on land tax, crop tax, both Muslim and nonMuslim. For the tax period, Umar does not differentiate between Muslims and nonMuslims; they both have tax obligations. The second distinguishes between the jizyah tax and the Kharaj tax. The jizyah tax is abolished for non-Arab Muslims. This shows us that Umar has equalized the rights of Arabs and non-Arabs who are only based on the same Islamic Aqidah. This Mawali is automatically erased in his time, to support the abolition of Mawali, the assimilation of marriages between Arabs and non-Arabs should be encouraged. As for the Kharaj tax between Muslims and Muslims or between Arab and non-Arab alike. Zakat is also imposed on Muslims only. The third is eliminating all celebrations (Mahrajan), lavish parties' habit, and giving away gifts because this includes waste and misuse of people's property. Bani Umayyad takes Agriculture and transportation during Umar's time were also taken into account by other provinces in European Umayyad. This is done by repairing and reviving unproductive lands to support the digging of many new wells. Roads and accommodation for people traveling long distances were designed to recognize his concern for change., And not to forget that many mosques were made, but Umar did not care about their beauty. Umar did this because he gave more importance to the poor starving than funding to beautify walls and furniture. The state of the economy at the time of the Caliph Umar has entered into an extraordinary level. All the literature that is available to us reinforces that poverty, deprivation, and poverty are overcome. It can be said that those who want to pay zakat are very difficult to find people who are willing to receive. The step that has been taken is the equitable redistribution of state assets.

By restructuring the state organization, trimming the bureaucracy, simplifying the administrative system, Umar saved state spending, and at the same time, socialized the spirit of business and entrepreneurship in the community. In this way, Umar enlarges the sources of state income through zakat, taxes, and jizyah. In the concept of zakat distribution, the determination of the eight objects of zakat recipients or Mustahiq means that a zakat is a form of direct subsidy. Zakat must have an empowering impact on people with low purchasing power. So that by increasing their purchasing power, zakat directly stimulates the growth of demand from the community, which encourages increased supply. With the increase in public consumption, production will also increase. Thus, the distribution pattern of zakat not only impacts the loss of absolute poverty but can also be a stimulating factor for economic growth at the macro level. That is what happened during the time of Umar Bin Abdul Aziz. The number of zakat payers increases, while the number of zakat recipients decreases, even ultimately. The Amil zakat travels all over Africa to distribute zakat, but no one wants to accept zakat. The Mustahiq zakat is wholly depleted in absolute terms so that the country experiences a surplus. The redistribution of state wealth is further directed towards subsidizing the payment of private (private) debts and social subsidies in the form of financing basic needs that are 
not borne by the state, such as marriage expenses. One time due to an excess surplus, the state announced that "the state will cover all the costs of marriage for every young man who wants to get married at a young age." Yahya Ibn Sa'id brought a narration: It was said that Umar Ibn Abdul 'Aziz had sent me to North Africa to distribute zakat for the people there. So I carried out the order, then I looked for poor people to give zakat to them. But I didn't get anyone, and we didn't find anyone who would accept it. Umar made his people prosperous. Finally, I bought with the zakat some of my slave servants, which I then freed. Our scholars even call Umar Bin Abdul Aziz a reformer of the first century of Hijri, even referred to as the fifth Khulafa Rashidin. Maybe the prosperity indicators that existed at that time would never be repeated, namely when the Amil zakat wandered around in African villages. Still, they did not find anyone willing to accept zakat. The state ran a surplus, even to the extent that the state bore personal debts and the citizen's marriage costs. Umar's improvements also included the postal service. The postal service serves not only to convey the governor and officials' official news to the caliph but also to serve the people's interests. Umar ordered the postal clerk to accept all letters submitted by people to deliver to those entitled.

Umar carried out the Islamic da'wah to the non-Islamic groups by using sound wisdom and lessons and sending religious teachers to all countries by choosing whichever place he likes. Those who have not embraced Islam are given the right and freedom of worship. This shows that religious tolerance was instilled during the time of Umar Ibn Abd Al_'Aziz. And to deal with the Khawarij, Umar relied more on dialogue by including strong arguments so that their intellect could accept them. Umar Ibn Abd Al-'Aziz also eliminated the curse on Ali bin Abu Talib on the pulpits while the Umayyads people insulted him. This is not surprising since Umar was a caliph who had followed in his father's footsteps, Abdul 'Aziz in Egypt. It is narrated from it that his late father came to Amirul Mukminin Ali's mention stuttered. At that time, Umar asked: Why did your father act like that? He replied: O, son! You know, if ordinary people know about Ali Bin Abu Talib as we know, their hopes will run away from us, and they will indeed join their son. Therefore, at the time of Umar, the part used to insult was replaced by the verse al-Quran surah al-Nahl: 90

Umar also issued a policy of returning pension funds for orphans left by their parents who died on the battlefield. At the beginning of the Umayyad dynasty, many pension money for Muslim fighters who died on the battlefield were not given to their families. This made the families of the Muslim soldiers who died, especially the orphans, dissatisfied. ${ }^{32}$

\section{Declined}

Several factors caused the Umayyad dynasty to be weak and brought it to ruin. These factors include:

1. Changing the Caliphate through lineage is something new (Heresy) for the Islamic tradition that emphasizes seniority. The settings are unclear. The lack of clarity on changing the Caliphate has resulted in unfair competition among the royal family members. The background to the formation of the Bani Umayyah dynasty cannot be separated from the political conflicts that occurred during Ali's time. The Shiah remnants and the Khawarij continued to be opposition movements, both openly as in the early and late times and secret as in the mid-reign of the Bani Umayyah. The suppression of these movements drained the power of the government a lot. During the reign of the Umayyads, the ethnic conflict between the tribes of North Arabia (Banu Qays) and South Arabia (Bani Kalb), which had existed since pre-Islamic times, became more acute. This dispute made it difficult for the Umayyad rulers to build unity and integrity. Besides, most of the Mawali (non-Arab) groups, especially in Iraq and other eastern regions, were dissatisfied because the status of the Mawali

32

http://referensiagama.blogspot.com/2011/01/ko nsolidasi-dan-pembaharuan-politik.html 
represented inferiority, coupled with the arrogance of the Arab nation that was shown during the time of the Umayyads. The Umayyad sovereign government's weakness was also caused by the luxurious lifestyle in the palace environment. The caliph children were unable to carry the heavy burden of the state when they inherited power. Besides that, many Ulama were disappointed because the authorities' attention to religion's development was very lacking. The direct cause of the Umayyad dynasty's overthrow was the emergence of a new power spearheaded by al-Abbas ibn Abd al-Muttalib's descendants. This movement received the Bani Hashim's full support and the Mawali, who felt second classed by the Bani Umayyah government.

\section{CLOSING}

During the reign of the Umayyads, many economic policies were formed based on ijtihad. Since the Abbasid era, even though they were still carried out individually, banking began to develop rapidly when there were many types of currencies in circulation at that time. So that particular expertise was needed to distinguish between one currency and another, Caliph Uthman ibn Affan maintained a system of providing assistance and compensation and gave large sums of money to different communities. The above changes can be seen that the government system during the Ummayah and Abbasid Daulah was other than what was applied during the Khulafaur Rasyidin period. Between the Umayyad and Abbasid, Daula also differs. It can be seen during the Khulafaur Rasyidin period that the election of leaders was carried out with a Syuro council, while during the Umayyad period, it was carried out in a monarchical manner (hereditary). In the middle ages of Islam, Islamic civilization was international. Because at that time, Islam had controlled the regions in three significant continents; Europe, Asia, Africa. Islamic culture has progressed very rapidly in various religious knowledge, architecture, science and technology, and others, especially economics. ${ }^{33}$ The decline of these dynasties was due to many reasons. It can be divided into external and internal factors. History is a right mirror, which can always inspire us to face difficult times in our life. Like today, when our nation is plunged into a multidimensional crisis that is complex and complex, it drags on and feels so tiring. This may be the right time to look for a slice of time in history, against the backdrop of problems that seem similar to what we face, or at least in some aspects, to then find permanent rules that govern and control them. What Umar bin Abdul Aziz did was reconcile justice with prosperity. When pious, strong leaders are presented at the crossroads of history to solve a people and a nation's crisis, and it can happen again if the same terms and conditions are repeated. And this is our problem: historical repetition does not occur because the needs are not met. Caliph Umar Ibn Abd Al-'Aziz was a caliph who could provide light in the dark, who brought an oasis of thirst. With his heart and mind's brilliance, he could create a civilization that would apply to all ages. He has inspired the Muslim world and outside of Islam to become leaders who are just, not corrupt, pro-people (Ummah) based on Islam. Almost all lifelines have been renewed by Umar, economics, social, political, and culture without exception.

\footnotetext{
Ajid Thohir, Perkembangan peradaban di kawasan dunia Islam: melacak akar-akar sejarah, sosial, politik, dan budaya umat Islam, Cet. 1 edition (Jakarta: Divisi Buku Perguruan Tinggi, RajaGrafindo Persada, 2004), p. 79.
} 


\section{BIBLIOGRAPHY}

Abdullah, H. Boedi and H. Hendi Suhendi, Peradaban pemikiran ekonomi Islam, Bandung: Pustaka Setia, 2010.

Borrut, Antoine et al. (eds.), Umayyad legacies: medieval memories from Syria to Spain, 2010.

Developing Inclusive and Sustainable Economic and Financial System: Selected papers presented to the 8th and 9th International Conference on Islamic Economics and Finance, Qatar: Bloomsbury Qatar Foundation Journals, 2015.

Farah, Naila, PERKEMBANGAN EKONOMI $D A N$ ADMINISTRASI PADA MASA BANI UMAYYAH DAN BANI ABBASIYAH, p. 26.

Hakim, Yahya, 'The HashemiteUmayyad Divide and its Impact on the Future of Islam: The Hashemite-Umayyad Divide and its impact on the future of Islam', The Muslim World, vol. 106, no. 1, 2016, pp. 83-96 [https://doi.org/10.1111/muwo.12 $125]$.

Hasan, 'Īsá, al-Dawlah al- 'Umawīyah: 'awāmil al-binā' wa-asbāb alinhiyār, al-Ṭab'ah 1 edition, 'Ammān: al-Ahlīyah lil-Nashr wa-al-Tawzī', 2009.

Hawting, G.R., The first dynasty of Islam: the Umayyad caliphate $A D$ 661-750, 2nd ed edition, London; New York: Routledge, 2000.

Hitti, Philip K., 'The Umayyad Caliphate: Mu'āwiyah Establishes a Dynasty', in History of the Arabs, London:
Macmillan Education UK, 1970,

pp.

189-98

[https://doi.org/10.1007/978-1-

349-15402-9_17].

Ibn Kathīr, Ismā'îl ibn 'Umar, The caliphate of Banu Umayyah: the first phase: taken from alBidayah wan-nihayah, Riyadh: Maktaba Dar-us-Salam, 2012.

Jayyusi, Salma Khadra and Manuela Marín (eds.), The legacy of Muslim Spain, 2nd ed edition, Leiden; New York: E.J. Brill, 1994.

Meirison, Meirison, 'Islamic Tolerance on Religious Freedom, Culture and Thought in Andalusia', HIKMATUNA; Vol 6 No 1 (2020): HIKMATUNA: Journal for Integrative Islamic Studies, Juni 2020DO

10.28918/hikmatuna.v6i1.2313, 2020, http://ejournal.iainpekalongan.ac.id/inde x.php/hikmatuna/article/view/231 3.

----, 'ADMINISTRATION AND FINANCE SYSTEM OF THE OTTOMAN EMPIRE', Jurnal Ilmiah Al-Syir'ah, vol. 18, no. 2, 2020, p. 91 [https://doi.org/10.30984/jis.v18i 2.1113].

Sali, Meirison Alizar, 'Distinction of Justice and Fairness during Umar bin Abdul Aziz?s Reign', AJIS: Academic Journal of Islamic Studies, vol. 4, no. 2, 2019, p. 127

[https://doi.org/10.29240/ajis.v4i 2.954].

Suñé Arce, Josep, 'Was the Umayyad Caliphate of Cordoba as Strong as Arab Chroniclers Claimed?', Al-Masāq, vol. 31, no. 1, 2019, 
pp.

[https://doi.org/10.1080/0950311 $0.2018 .1553376]$.

Thohir, Ajid, Perkembangan peradaban di kawasan dunia Islam: melacak akar-akar sejarah, sosial, politik, dan budaya umat Islam, Cet. 1 edition, Jakarta: Divisi Buku Perguruan Tinggi, RajaGrafindo Persada, 2004.

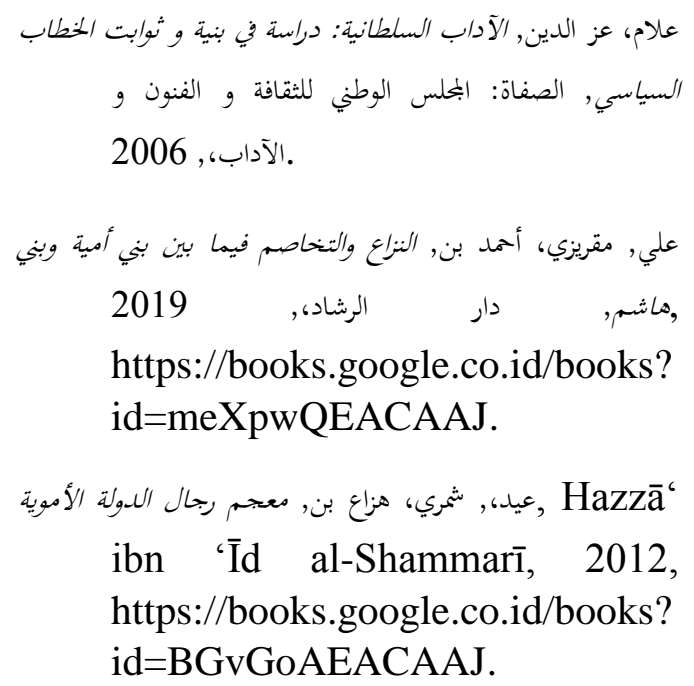

